\title{
Direct Vs Indirect Digital Systems: Local Diagnostic Reference Levels for Chest Radiography in Postero-Anterior Projection in two Portuguese Hospitals
}

\author{
Sistemas Digitais Directos Vs Indirectos: Níveis de Referência de Diagnóstico Locais na \\ Radiografia de Tórax em Projeção Postero-Anterior em dois Hospitais Portugueses
}

\author{
Joana Oliveira $^{1}$; Marília Mourato ${ }^{1}$; Carlos Domingos ${ }^{1}$; Ricardo Miranda ${ }^{1}$; Paulo Pereira ${ }^{1}$; \\ Ricardo Grilo²; Jorge Frutuoso ${ }^{2}$ \\ ${ }^{1}$ Radiologia, ERISA - Escola Superior de Saúde Ribeiro Sanches, Rua do Telhal aos Olivais, n8 - 8a, 1900-693 Lisboa \\ ${ }^{2}$ Técnicos de Radiologia Centro Hospitalar Oeste Norte, Rua Diário de Noticias, 2500-176 Caldas da Rainha \\ Email: pjmarquespereira@gmail.com
}

\begin{abstract}
This study intended to evaluate and compare radiation doses collected from a sample of 69 patients in two hospitals where chest radiography is carried out using different methods of digital image acquisition, direct and indirect, in postero-anterior (PA) projection. For the two hospitals, entrance skin doses $(E S D)$ and effective dose $(E)$ were measured using PCXMC software for posterior comparison with each other, as well as with international references. For Hospital A, with direct digital acquisition, average ESD was $0,089 \mathrm{mGy}$ and average $E$ was $0,013 \mathrm{mSv}$.

For Hospital B, with indirect digital acquisition, average $E S D$ was $0,151 \mathrm{mGy}$ and average $E$ was $0,030 \mathrm{mSv}$. In both hospitals, average doses did not exceed the limits recommended by law (0,3 mGy).

In the chest X-ray, in PA projection, the local DRLs calculated were $0.107 \mathrm{mGy}$, in Hospital A and $0.164 \mathrm{mGy}$, in Hospital B.

In chest PA radiography, the utilization of a direct acquisition system implies a dose decrease of $41 \%$, in agreement with the available references that point to dose reductions of around $50 \%$ between the direct and indirect acquisition systems.
\end{abstract}

Keywords: Diagnostic Reference Levels; Entrance Skin Dose; Effective Dose; PA Chest Radiography; Good Radiological Practice.

\section{Resumo}

Este estudo teve como objetivo avaliar e comparar as doses de radiação recolhidas numa amostra de 69 pacientes, em dois hospitais, com diferentes métodos de aquisição de imagem digital, direta e indireta, que realizaram radiografia de tórax, em projeção postero-anterior (PA). Para os dois hospitais, a dose à entrada da pele $(D E P)$ e efectiva $(E)$, foram medidas usando o software PCXMC para comparação entre si e com referências internacionais. No Hospital A, com aquisição digital direta, a média de $D E P$ foi de $0,089 \mathrm{mGy}$ e a média de $E$ foi $0,013 \mathrm{mSv}$.

No Hospital B, com aquisição digital de indireta, a média de DEP foi de $0.151 \mathrm{mGy}$ e a média de E foi $0.030 \mathrm{mSv}$. Em ambos os hospitais, as doses médias não ultrapassaram os limites recomendados por lei (0,3 mGy). Para a radiografia de tórax PA, o nível de referência diagnostico (NRD) local calculado foi 0.107 mGy, para o Hospital A e 0.164 mGy, para o Hospital B. Na radiografia de tórax PA, a utilização de um sistema de aquisição direta implicou uma redução de dose de $41 \%$, concordante com as referências disponíveis que apontam para a redução da dose de cerca de $50 \%$ entre os dois sistemas.

Palavras-Chave: Níveis de Referência Diagnóstico; Dose à Entrada da Pele; Dose Efetiva; Radiografia Tórax PA; Boas Práticas Radiológicas. 


\section{Introduction}

The exposure to ionizing radiation sources is largely due to radiological examinations.

The protection of patients is done not only through the correct use of the equipment and its technical factors (exposure time, $\mathrm{kVp}$ and $\mathrm{mAs}$, grides, collimation, etc.), but also through the practical use of the principles of protection: the Principle of Justification and the Principle of Optimization.

The potential value of an exposure to ionizing radiation should be determined taking into account that its benefits should always outweigh the risks. Therefore the examination is justified if it will positively influence the diagnosis and directly benefit the management of the patient's clinical condition, assuming the best possible use of available resources in an attempt to minimize the risks.

These two principles are the basis of ALARA (As Low As Reasonably Achievable) philosophy ${ }^{(1,2)}$.

To reduce the levels of exposure to ionizing radiation and prevent its consequences, measures must be taken which involve adhering to correct working habits.

The level of exposure to patients in radiology departments depends on many physical and technical factors which should be checked periodically to maintain quality of service. This is of great importance in the implementation of methodologies which determine the estimated entrance skin dose (ESD) of the patient, reliably and with fast execution, in order to meet the legislation requirements ${ }^{(3)}$.

$E S D$ can be measured directly or indirectly: directly through instruments such as ionization chambers and dosimeters, and indirectly, through the technical parameters used in the exposure and use of computer programs, such as $P C X M C$, based on the method of Monte Carlo simulation $^{(4)}$.

In radiological examinations, the PA chest radiography is performed most frequently and contributes most to the collective dose. In the United States in 2006, 281 million radiographic exams were performed of which 129 million were chest radiographs ${ }^{(5)}$.

In Portugal in 2010, 4184154 chest radiographs were performed with an average of 396380 chest radiographs per million inhabitants ${ }^{(6)}$.

These values leave Portugal in $9^{\text {th }}$ place in a universe of 33 European countries where collective doses were evaluated ${ }^{(7)}$.

For the PA chest radiography - as for other radiographic examinations - standards of good practice are described which aim to reduce the levels of dose to which patients are subjected during the exposure.

\section{Introdução}

A exposição a fontes de radiação ionizante é, em grande parte devido a exames radiológicos.

A proteção dos doentes é feita, não só através da utilização correta do equipamento e dos seus fatores técnicos (tempo de exposição, mAs e $\mathrm{kVp}$, grelhas anti-difusoras, colimação, etc), como da utilização prática dos princípios fundamentais de proteção radiológica: o Princípio da Justificação e o Princípio da Otimização.

O potencial valor de uma exposição a radiações ionizantes deve ser determinado tendo em consideração que os seus benefícios devem sobrepor-se sempre aos riscos.

O exame radiológico é justificado, se influenciar positivamente o diagnóstico e implicar um benefício direto para a gestão da situação clínica do doente, implicando a melhor utilização possível dos recursos disponíveis, na tentativa de minimizar os riscos.

Estes dois princípios formam assim a base do princípio ALARA - As Low As Reasionably Achievable ${ }^{(1,2)}$.

Para reduzir os níveis de exposição à radiação ionizante devem ser adotadas medidas que previnam as consequências das mesmas, através de hábitos de trabalho corretos. O nível de exposição aos pacientes, em serviços de radiologia, depende de muitos fatores físicos e técnicos, que devem ser verificados periodicamente para manter a qualidade do serviço, sendo de grande importância a implementação de metodologias que permitam a determinação da dose à entrada da pele $(D E P)$, de forma confiável e de execução rápida, de modo a cumprir as exigências da legislação ${ }^{(3)}$.

A $D E P$ pode ser medida de forma direta ou indireta. De forma direta através de instrumentos próprios, como por exemplo, câmaras de ionização e dosímetro termoluninescentes (TLD), e de forma indireta, através dos parâmetros técnicos utilizados na exposição e da utilização de programas informáticos, como por exemplo o $P C X M C$, baseado no método de simulação de Monte Carlo ${ }^{(4)}$.

Nos exames radiológicos, aquele que é realizado com mais frequência e mais contribui para a dose coletiva é a radiografia de tórax PA. Nos Estados Unidos, em 2006, foram realizados 281 milhões exames radiográficos dos quais 129 milhões eram radiografias de tórax ${ }^{(5)}$.

Em Portugal, no ano de 2010, foram realizados 4184154 radiografias de tórax com uma média de 396,380 radiografias de tórax por milhão de habitantes ${ }^{(6)}$.

Estes valores deixam Portugal em $9^{\circ}$ lugar, num universo de 33 Países Europeus onde foram avaliadas as doses coletivas ${ }^{(7)}$.

Para a radiografia de tórax PA, como para os restantes exames radiográficos, estão descritas normas de boas práticas que têm como objetivo reduzir os níveis de dose a que os pacientes estão sujeitos durante a exposição. 
These standards were initially described in the European Guidelines ${ }^{(8)}$, the responsibility of the European Commission, and subsequently updated by the working group Dimond III ${ }^{(9)}$. In the United States, the American College of Radiology $(A C R)^{(10)}$ also produces normative for the optimization of various radiological examinations. According to the documents referred to, table 1 presents a synthesis of the standards of good practice described for $P A$ chest radiography which are:
Essas normas foram, inicialmente, descritas nas European Guidelines ${ }^{(8)}$, da responsabilidade da comissão europeia, e posteriormente atualizadas, para o domínio da radiologia digital, pelo grupo de trabalho Dimond III ${ }^{(9)}$. Nos Estados Unidos, o American College of Radiology $(\mathrm{ACR})^{(10)}$ produz, também, normativas para a otimização dos mais diversos exames radiológicos.

De acordo com os documentos referidos, a tabela 1 descreve sintetizadamente as normas de boas práticas para a radiografia de tórax PA que são:

Table 1 - Resume of good practice for PA chest radiography.

Tabela 1 - Resumo das boas práticas de referência para a radiografia de Tórax PA.

\begin{tabular}{|c|c|c|c|}
\hline & European Guidelines & Dimond III & ACR \\
\hline Potter & $\begin{array}{l}\text { Vertical with grid } \\
\text { Vertical com Grelha }\end{array}$ & $\begin{array}{l}\text { Vertical with grid } \\
\text { Vertical com Grelha }\end{array}$ & $\begin{array}{l}\text { Vertical with grid } \\
\text { Vertical com Grelha }\end{array}$ \\
\hline $\begin{array}{l}\text { Focus } \\
\text { Foco } \\
\end{array}$ & $\leq 1,3$ & $\leq 1,3$ & $\leq 1,3$ \\
\hline $\begin{array}{l}\text { Total Filtrage } \\
\text { Filtragem Total } \\
\end{array}$ & $\geq 3,0 \mathrm{~mm} \mathrm{Al}$ equivalent & $\geq 3,0 \mathrm{~mm} \mathrm{Al}$ equivalent & $\geq 3,0 \mathrm{~mm} \mathrm{Al}$ equivalent \\
\hline $\begin{array}{l}\text { Grid } \\
\text { Grelha }\end{array}$ & $\mathrm{r}=10 \mathrm{~cm} \mathrm{x} 40 \mathrm{~cm}$ & $\mathrm{r}=10 \mathrm{~cm} \mathrm{x} 40 \mathrm{~cm}$ & $\mathrm{r}=10 \mathrm{~cm} \times 12 \mathrm{~cm}$ \\
\hline $\mathrm{D}_{\mathrm{Fo}-\mathrm{Ri}}$ & $180 \mathrm{~cm}$ ou/or $[140 ; 200] \mathrm{cm}$ & $180 \mathrm{~cm}$ ou/or $[140 ; 200] \mathrm{cm}$ & $180 \mathrm{~cm}$ \\
\hline $\begin{array}{l}\text { AEC } \\
C A E\end{array}$ & $\begin{array}{l}\text { Right } \\
\text { Direita }\end{array}$ & $\begin{array}{l}\text { Both } \\
\text { Ambas }\end{array}$ & $\begin{array}{c}\text { Both } \\
\text { Ambas }\end{array}$ \\
\hline $\begin{array}{l}\text { Voltage } \\
\text { Tensão Elétrica }\end{array}$ & $125 \mathrm{kV}$ & $125 \mathrm{kV}$ & {$[120 ; 150] \mathrm{kV}$} \\
\hline $\begin{array}{l}\text { Exposition Time } \\
\text { Tempo de Exposição }\end{array}$ & $<20 \mathrm{~ms}$ & $<20 \mathrm{~ms}$ & - \\
\hline $\begin{array}{l}\text { Protection } \\
\text { Proteção }\end{array}$ & Standard & Standard & Standard \\
\hline
\end{tabular}

For radiographic examinations, the European Guidelines ${ }^{(8)}$ present values for the reference dose limit. For $P A$ chest examinations, the guidelines state the threshold dose for standard patients (weight between $70 \mathrm{Kg}$ and $75 \mathrm{~kg}$ and a height between $170 \mathrm{~cm}$ and $175 \mathrm{~cm}$ ) should be $0.3 \mathrm{mGy}$. However, the European Guidelines take into account that given the small number of patients of standard size in some countries, it is possible to collect data relating to all patients during a period of measurement in order to obtain an average dose. This can be done as long as the sample size is not too small, indicating that the sample must include at least 10 patients $^{(9)}$.

To prevent the entrance skin dose being greater than
Para os exames radiográficos as European Guidelines ${ }^{(8)}$ apresentam valores referência para o limite de dose. Para o exame de tórax PA, estas descrevem que o valor limite de dose, para pacientes standards (massa entre $70 \mathrm{Kg}$ e $75 \mathrm{Kg}$ e altura entre $170 \mathrm{~cm}$ e $175 \mathrm{~cm}$ ), deve ser 0,3 mGy. No entanto, as orientações europeias prevê que, dado o pequeno número de pacientes de tamanho padrão, em alguns países, é possível recolher todos os dados relativos a todos pacientes durante um período de medição, para obter uma dose média, que será utilizada como sendo o resultado em relação a pacientes de tamanho padrão, garantido sempre que o tamanho da amostra não é muito pequeno, sugerindo assim, a recolha de uma amostra de pelo menos 10 pacientes ${ }^{(9)}$. 
what is stated, the concept of diagnostic reference levels $(D R L s)$ was established. In recent years this concept has become extremely important in preventing the improper administration of doses of radiation.

The DRLs are designed to compare the radiation doses of various radiological equipments with the doses obtained in other similar equipment, as recommended by the American Association of Physicists in Medicine.

These were developed by the Nationwide Evaluation of $\mathrm{X}$-ray Trends through a survey conducted by the agency for radiation protection, in collaboration with the U.S. Food and Drug Administration (FDA), the Conference of Radiation Control Program Directors, and the American College of Radiology ${ }^{(12)}$.

Over the years, the equipment and radiological examinations have been undergoing changes in order to obtain better images of diagnostic quality, respecting the principles of optimization in order to reduce the radiation doses administered to patients ${ }^{(10)}$.

It is expected that the progression from conventional radiology to digital radiology will lead to increased spatial resolution, a decrease in dose values of $50 \%$ and more rapid and direct readings $(10,13,14)$.

This study aimed to evaluate the radiation dose associated with the realization of chest PA radiography at two hospitals. The study was undertaken in order to subsequently determine local DRLs, compare the acquisition systems between the two hospitals and with international references, and to verify good practices and the principles of optimization in both services.

\section{Material and Methods}

A descriptive, correlational and cross-sectional study was performed on the adult patients subjected to the examination of chest radiography in PA incidence, in the accident and emergency rooms in two hospitals. The Lisbon region corresponds to Hospital A and Hospital $\mathrm{B}$ to the Leiria region.

Data for the study were collected during the period February to May 2012, with a sample composed of 69 standard patients, 27 from Hospital A and 42 from Hospital B.

The examinations were performed using radiological equipment with direct digital acquisition (Hospital A) and indirect digital acquisition (Hospital B).

In addition to the physical characteristics (gender, weight and height) technical information was collected regarding the factors used in each examination: applied
Para evitar que a $D E P$ fosse maior do que a que está descrita, foi criado o conceito de Nível de Referencia de Diagnóstico $(N R D)$. Este conceito tornou-se, nos últimos anos, de extrema importância na prevenção da administração inapropriada de doses de radiação.

Os $N R D$ têm como objetivo comparar as doses de radiação, dos vários equipamentos radiológicos, com as doses obtidas noutros equipamentos similares, sendo recomendados pela American Association of Physicists in Medicine.

Estes foram desenvolvidos pela Nationwide Evaluation of X-ray Trends através de uma vistoria realizada pelas agências de proteção contra a radiação, com a colaboração da U.S. Food and Drug Administration, da Conference of Radiation Control Program Directors, e do American College of Radiology ${ }^{(12)}$.

Ao longo dos anos, os equipamentos e exames radiológicos têm vindo a sofrer alterações, com vista à obtenção de imagens de melhor qualidade diagnóstica, respeitando os princípios de otimização a fim de diminuir as doses de radiação administradas aos pacientes ${ }^{(10)}$. Com o avanço da radiologia convencional para a radiologia digital é expectável que este conduza ao aumento da resolução espacial, à diminuição dos valores de dose de cerca de $50 \%$ e a uma leitura mais rápida e direta $(10,13,14)$.

Este estudo teve como objetivo avaliar a dose de radiação associada com a realização de radiografia tórax PA, nos dois hospitais do estudo para posterior determinação de NRD locais, comparar os sistemas de aquisição entre si e com referências internacionais, verificar as boas práticas e os princípios de otimização em ambos os serviços.

\section{Material e Métodos}

Foi realizado um estudo descritivo, correlacional e transversal, a pacientes adultos sujeitos à realização de radiografia de tórax, em incidência $\mathrm{PA}$, nas urgências de dois Hospitais. O Hospital A situa-se na região de Lisboa e Hospital B na região de Leiria.

Os dados para o estudo foram recolhidos no período de Fevereiro a Maio de 2012, sendo a amostra composta por 69 pacientes padrão, 27 do Hospital A e 42 do Hospital B.

Os exames foram realizados com recurso a equipamentos radiológicos de aquisição digital direta (Hospital A) e de aquisição digital indireta (Hospital B).

Para além das características físicas do paciente (género, peso e altura) foram recolhidas informações sobre os fatores técnicos utilizados em cada exame: tensão elétrica aplicada (de símbolo " $U$ " e símbolo de unida- 
voltage (of symbol " $U$ " with unit symbol " $k V^{\prime \prime}$ ), tube current (of symbol " $J$ " with unit symbol " $m A "$ ), exposure time (ms), Focus Distance - Receiver Image (DFo - Ri) and the use and configuration of Automatic Exposure Control (AEC).

Following the orientations of the European Guidelines (10), data were collected only from median patients weighing between $60 \mathrm{Kg}$ and $80 \mathrm{~kg}$ and with a height of between $160 \mathrm{~cm}$ and $180 \mathrm{~cm}$, and the exposures were conducted in compliance with good practice reference $\left([120 ; 150] \mathrm{kV}, \mathrm{D}_{\mathrm{Fo}-\mathrm{Ri}}\right.$ of $180 \mathrm{~cm}$, the use of $A E C$ and exposure time $<20 \mathrm{~ms}$ ).

The ESD and Effective Dose $(E)$ values for patients exposed were calculated using the computer program PCXMC version 2.0, based on the method of Monte Carlo simulation.

The ESD values were obtained using the following formula:

$\mathrm{Ka}, i$ is incident Kerma (in PXCMC corresponding to the value of Surface dose);

$B S F$ is Backscattering factor.

Due to the impossibility of calculating the value of $B S F$ for each exposure, the value 1.35 was adopted, according to the indications of the European Guidelines ${ }^{(8)}$ for a standard patient.

For the treatment and statistical analysis, we used the software SPSS version 19.0 (Statistical Package for the Social Sciences).

Statistical analysis of the sample was characterized based on measures of central tendency and dispersion.

Parametric tests were used in the comparative analysis, t-Student and Pearson correlation, because all presuppositions were verified for their use.

\section{Results}

The data collected refer to 69 patients who used the Radiology Department Hospitals in order to undergo a chest radiograph in Postero-Anterior incidence (PA). In Hospital A data for 27 patients $(39,1 \%)$ were collected and $42(60,9 \%)$ in Hospital B (Table 4).

In Hospital A, $11,1 \%$ of the sample consisted of females $(N=3)$ and $88,9 \%$ were male $(N=24)$. In Hospital B, $40,5 \%$ of subjects were female $(N=17)$ and $59.5 \%$ were male $(N=25)$.

In Hospital $A$, the mean age was $(50,19 \pm 19,24)$ years, covering a range of ages between 20 and 80 years. In Hospital B the average age was $(53,81 \pm 18,44)$ years, with a range of ages between 22 and 85 years.

With respect to the physical characteristics of the pa- de " $k V^{\prime \prime}$ ), corrente elétrica do tubo (de símbolo " $J "$ e símbolo de unidade " $m A$ ", Tempo de exposição (mS), Distância Foco - Recetor de Imagem (DFo - Ri) e utilização e configuração de Controlo Automático de Exposição (CAE).

Segunido as orientações das European Guidelines ${ }^{(10)}$, apenas foram recolhidos dados de pacientes considerados médios, com massa entre os $60 \mathrm{Kg}$ e $80 \mathrm{Kg}$ e altura entre $160 \mathrm{~cm}$ e $180 \mathrm{~cm}$, e cujas exposições foram realizadas respeitando as boas práticas de referência ([120; $150] \mathrm{kV}, \mathrm{D}_{\mathrm{Fo}-\mathrm{Ri}}$ de $180 \mathrm{~cm}$, utilização das CAE e tempo de exposição $<20 \mathrm{~ms}$ ).

Os valores de $D E P$ e dose efetiva $(E)$, para os pacientes expostos, foram calculados através de do programa informático $P C X M C$ versão 2.0, baseado no método de Simulação de Monte Carlo.

Os valores de DEP foram obtidos utilizando a seguinte fórmula:

Ka,i é Kerma incidente (no PCXMC corresponde ao valor de "Surface Dose");

BSF é o factor de retrodispersão.

$\mathrm{Na}$ impossibilidade de calcular este valor para cada exposição, foi adotado o valor 1.35 , de acordo com as indicações das European Guidelines ${ }^{(8)}$ para um paciente standard.

Para o tratamento e análise estatística, utilizou-se o Software SPSS versão 19.0 (Statistical Package for the Social Sciences).

A análise estatística da amostra foi caracterizada com base em medidas de tendência central e dispersão.

Para a análise comparativa utilizaram-se teste paramétricos, $t$-student e a correlação de Pearson, porque todos os pressupostos para a sua utilização foram verificados.

\section{Resultados}

Os dados recolhidos referem-se a 69 pacientes que recorreram ao Serviço de Imagiologia dos Hospitais avaliados, afim de realizar uma radiografia do tórax, em incidência Postero-Anterior (PA).

Do Hospital A foram recolhidos dados relativos a 27 pacientes $(39,1 \%)$ e $42(60,9 \%)$ do Hospital B.

No Hospital A, 11,1\% da amostra era composta por indivíduos do sexo feminino $(N=3)$ e $88,9 \%$ do sexo masculino $(N=24)$. No Hospital B, 40,5\% dos indivíduos são do sexo feminino $(N=17)$ e $59,5 \%$ do sexo masculino $(N=25)$.

No Hospital A, a média de idades era de $(50,19 \pm 19,24)$ anos, abrangendo um intervalo de idades entre os 20 e 80 anos. No Hospital B a média era de $(53,81 \pm 18,44)$ 
tients, the mean weight observed in Hospital A was $(74,3 \pm 3,69) \mathrm{kg}$ and the mean height was $(1,75 \pm 0,325)$ m. In Hospital B average weight was $(71,9 \pm 5,70) \mathrm{kg}$ and height was $1,68 \pm 0,559 \mathrm{~m}$.

The Automatic Exposure Control (AEC) was used in all exams performed in both hospitals using the two lateral chambers.

The technical parameters used in hospitals were not equal. In Hospital A (125 \pm 0$) \mathrm{kV}$ were used and an average of $(1,25 \pm 0,42) \mathrm{mAs}$, while in Hospital B (137 $\pm 0) \mathrm{kVp}$ were utilized and on average $(2,74 \pm 0,66)$ mAs (Table 2).

The image receiver focus distance $\left(\mathrm{D}_{\mathrm{Fo}-\mathrm{Ri}}\right)$ was uniform in both hospitals; Hospital A used a $\mathrm{D}_{\mathrm{Fo}-\mathrm{Ri}} 180 \mathrm{~cm}$ in all examinations, and Hospital B a $\mathrm{D}_{\mathrm{Fo}-\mathrm{Ri}}$ of $183 \mathrm{~cm}$ (Table 2).

Table 2 - Statiscal resultus of technical parameters and dose values in both Hospitals.

Tabela 2 - Resultados estatísticos dos parâmetros técnicos e dos valores de dose em ambos os Hospitais.

\begin{tabular}{|c|c|c|c|c|c|}
\hline & & $\begin{array}{l}\text { Mean } \\
\text { Média }\end{array}$ & $\begin{array}{l}\text { Minimum } \\
\text { Minimo }\end{array}$ & $\begin{array}{l}\text { Maximum } \\
\text { Máximo }\end{array}$ & $\begin{array}{l}\text { Std Desviation } \\
\text { Desvio Padrão }\end{array}$ \\
\hline \multirow{5}{*}{ Hospital A } & $\begin{array}{l}\text { Electrical Tension, } \mathbf{U} / \mathbf{k V} \\
\text { Tensão elétrica, } U / \mathrm{kV}\end{array}$ & 125 & 125 & 125 & 0 \\
\hline & $\begin{array}{l}\text { Exposure, Q/ (mA s) } \\
\text { Exposição, } Q /(m A s)\end{array}$ & 1,25 & 0,70 & 2,40 & 0,42 \\
\hline & $\begin{array}{c}\text { Focus-Receptor Distance, } \mathbf{D}_{\mathrm{FO}-\mathrm{RI}} / \mathbf{m} \\
\text { Dist. Foco-Recetor, } D_{F O-R I} / m\end{array}$ & 1,80 & 1,80 & 1,80 & 0 \\
\hline & $\begin{array}{l}\mathbf{D E P} / \mathbf{m G y} \\
E S D / m G y\end{array}$ & 0,089 & 0,050 & 0,173 & 0,030 \\
\hline & $E / \mathrm{mSv}$ & 0,013 & 0,007 & 0,025 & 0,004 \\
\hline \multirow{5}{*}{ Hospital B } & $\begin{array}{l}\text { Electrical Tension, } \mathbf{U} / \mathbf{k V} \\
\text { Tensão elétrica, } U / \mathrm{kV}\end{array}$ & 137 & 137 & 137 & 0 \\
\hline & $\begin{array}{l}\text { Exposure, } \mathbf{Q} /(\mathbf{m A s}) \\
\text { Exposição, } Q^{/}(m A s)\end{array}$ & 2,74 & 1,63 & 4,83 & 0,66 \\
\hline & $\begin{array}{c}\text { Focus-Receptor Distance, } \mathbf{D}_{\text {FO-RI }} / \mathbf{m} \\
\text { Dist. Foco-Recetor, } D_{F Q-R I} / m\end{array}$ & 1,83 & 1,83 & 1,83 & 0 \\
\hline & $\begin{array}{l}\mathbf{D E P} / \mathbf{m G y} \\
E S D / m G y\end{array}$ & 0,151 & 0,088 & 0,269 & 0,037 \\
\hline & $E / \mathbf{m S v}$ & 0,030 & 0,018 & 0,051 & 0,007 \\
\hline
\end{tabular}

For Hospital A, the results obtained by the simulation program showed an $E S D$ mean of $(0,089 \pm 0,030) \mathrm{mGy}$. The ESD minimum in this hospital was $0,050 \mathrm{mGy}$ and the maximum was $0,173 \mathrm{mGy}$ (Fig.1). In relation to $E$, the average was $(0,013 \pm 0,004) \mathrm{mSv}$, and minimum and maximum values of $E$ were $0,007 \mathrm{mSv}$ of 0,025 $\mathrm{mSv}$ (Table 2).

For Hospital B, the average ESD observed was $(0,151$ $\pm 0,037$ ), while the ESD minimum was $0,088 \mathrm{mGy}$ and maximum $0,269 \mathrm{mGy}$ (Fig 1 ). In relation to $E$, there was an average of $(0,030 \pm 0,007) \mathrm{mSv}$, and minimum and maximum values of $E$ were $0,018 \mathrm{mSv}$ of 0,051 $\mathrm{mSv}$ (Table 2). anos, com um intervalo de idades compreendido entre os 22 e os 85 anos.

No que diz respeito às características físicas dos pacientes, o peso médio observado no Hospital A foi de (74,3 $\pm 3,69) \mathrm{Kg}$ e a altura $(1,75 \pm 0,325) \mathrm{m}$. No Hospital B, em média, foi observado uma massa de $(71,9 \pm 5,70)$ $\mathrm{Kg}$ e uma altura de $1,68 \pm 0,559 \mathrm{~m}$.

O Controlo Automático de exposição $(C A E)$ foi utilizado em todos os exames realizados em ambos os hospitais, utilizando-se as duas câmaras laterais.

Os parâmetros técnicos utilizados nos Hospitais não foram iguais, foram utilizados para o Hospital A (125 $\pm 0) \mathrm{kV}$ e, em média, $(1,25 \pm 0,42) \mathrm{mAs}$, enquanto no Hospital B foram utilizados $(137 \pm 0) \mathrm{kVp}$ e, em média, $(2,74 \pm 0,66) \mathrm{mAs}$ (Tabela 2). 


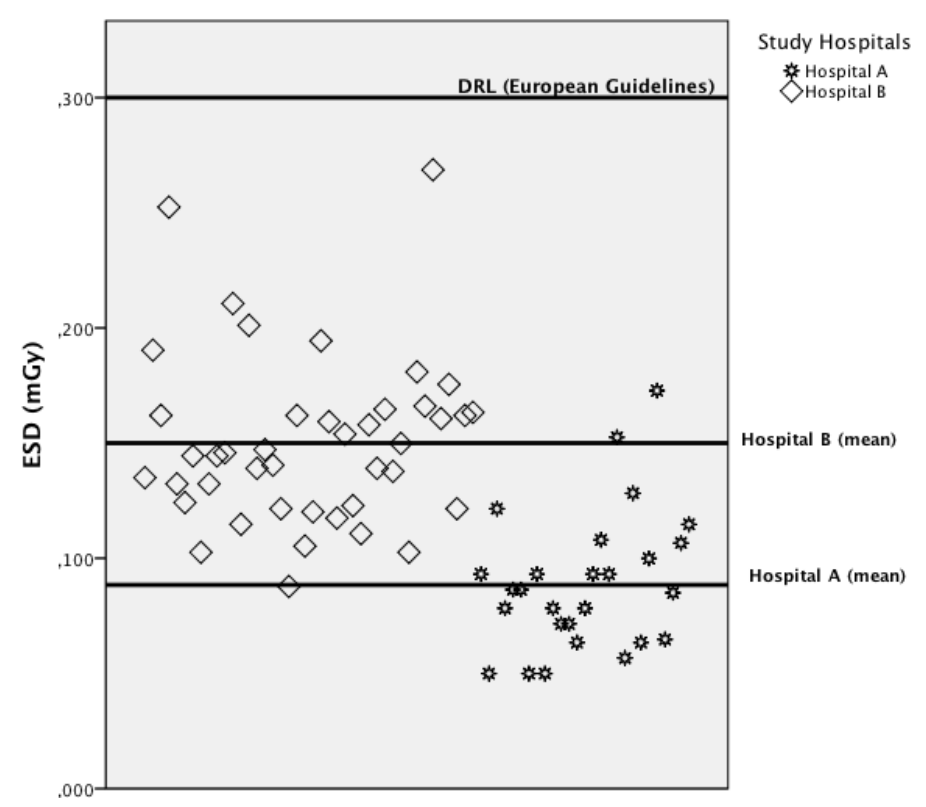

Figure 1 -. Variation of $E S D$ values to sample arround the mean and in relation do the $D R L$.

Figura 1 - Variação dos valores de $D E P$ da amostra em relaçao à média e em relação ao $N R D$.

Table 3 - Percentage of dose reduction to the Hospital A to Hospital B.

Tabele 3 - Percentagem de redução de dose do Hospital A para o Hospital B.

\begin{tabular}{|l|c|}
\hline & $\begin{array}{c}E S D / m G y \\
D E P / m G y\end{array}$ \\
\hline Hospital A & 0,089 \\
\hline Hospital B & 0,151 \\
\hline $\begin{array}{l}\text { \% of dose reduction } \\
\% \text { de redução de dose }\end{array}$ & $\mathbf{4 1 , 0 0 \%}$ \\
\hline
\end{tabular}

The percentage of dose reduction in Hospital A (direct acquisition) to Hospital B (computed radiology) was $41 \%$ (table 3 ).

Pearson Correlation was used to test the relationship between quantitative variables, and the degree of correlation between two variables was evaluated.

For both Hospitals the weight, the exposure (of symbol "Q" with unit symbol "mA s" and the applied voltage were correlated with $E S D$, verifying a weak relationship $(0,159)$ between the weight and the ESD, a strong correlation $(0,658)$ between the applied voltage and $E S D$, and a very strong relationship $(0,980)$ between the exposure and ESD.

The differences found between the values of ESD in the two hospitals were shown to be statistically significant $(p=0,000)$, as were the variables $U(p=0,000)$ and $Q$ $(p=0,000)$ and weight $(p=0,000)$.

To calculate the DRLs for the two hospitals the value of
$\mathrm{mSv}$, e os valores de $E$ mínima foram de $0,018 \mathrm{mSv}$ e máxima de $0,051 \mathrm{mSv}$ (Tabela 2).

A percentagem de redução de dose do Hospital A (aquisição direta) para o Hospital B (radiologia computorizada) foi de $41 \%$ (Tabela 3 ).

Para testar a relação entre as variáveis quantitativas, utilizou-se a Correlação de Pearson, e avaliou-se o grau de correlação entre duas variáveis. Para ambos os Hospitais a massa, a exposição (de símbolo "Q" e símbolo de unidade "mA s") e a tensão elétrica aplicada foram correlacionados com a $D E P$, verificando-se uma relação fraca $(0,159)$ entre a massa e a $D E P$, uma relação forte $(0,658)$ entre a tensão elétrica aplicada e a $D E P$, e uma relação muito forte $(0,980)$ entre exposições e a $D E P$.

As diferenças encontradas entre os valores de $D E P$, nos dois hospitais, mostraram ser estatisticamente significativas $(p=0,000)$, o mesmo acontecendo para as 
the $75^{\text {th }}$ percentile of $E S D$ was given in order to enable comparison with the DRLs known in the literature, the $D R L$ values for Hospital A being $0,107 \mathrm{mGy}$ and 0,164 mGy for Hospital B (table 4). variáveis $U(p=0,000), Q(p=0,000)$ e massa $(p=0,000)$. Para o cálculo dos $N R D$ dos dois Hospitais foi determinado o valor do percentil 75 da $D E P$ de forma a possibilitar a comparação com os $N R D$ conhecidos na literatura, tendo-se observado valores de DEP de 0,107 mGy para o Hospital A e 0,164 mGy para o Hospital B (Tabela 4).

Table 4 - Local $D R L$ for both Hospitals.

Tabela 4 - NRD Locais para ambos os Hospitais.

\begin{tabular}{|l|c|}
\hline & $\begin{array}{c}\boldsymbol{E S D} \text { percentil 75, } \boldsymbol{E S D}_{75} / \boldsymbol{m G} \boldsymbol{y} \\
\boldsymbol{D E P} \text { percentil 75, DEP }\end{array} /$ 75 $/ \mathrm{y}$ \\
\hline Hospital A & 0,107 \\
\hline Hospital B & 0,164 \\
\hline
\end{tabular}

\section{Discussion}

In order to optimize the exposure and the dose limit, standards of practice are outlined that aim to reduce the levels of dose to which patients are subjected during a given exposure.

In Portugal and in accordance with the $D L 180 / 2002^{(15)}$, if there are no reference values defined, European references should be adopted.

European Guidelines ${ }^{(8)}$, previously referred to, date back to 1996 and do not take into consideration the new paradigm of digital image. Later, the project Dimond III $^{(10)}$, also the responsibility of the European Commission, tried to adapt these standards to the new reality. However, there are no major changes concerning the examination in question.

More recent $A C R$ rules ${ }^{(11)}$ are very similar, although they consider the possibility of using higher voltages and accept the use of values within the interval $[120 ; 150] \mathrm{kV}$. For the purposes of this study, it is possible to admit that their combined use can transmit better perception of what is intended as standards of good practice.

However, different values of ESD found in the air give rise to the question: Is it just due to the different methods of image acquisition? Or could the different practices be the cause of, or contribute to these differences? The value of the difference found between the ESD in the two hospitals, $41 \%$, is in agreement with the available references that point to dose reductions of around $50 \%$ between the direct and indirect acquisition systems ${ }^{(13,14)}$.

In this way it would be possible to accept that there would be differences in technical procedures, responsible for the differences observed in this evaluation of ESD.

Considering the variables that most influence the ESD,

\section{Discussão}

De forma a otimizar a exposição e a limitar a dose, são descritas normas de boas práticas que têm como objetivo reduzir os níveis de dose a que os pacientes estão sujeitos durante uma determinada exposição. Em Portugal e de acordo com o DL 180/2002 ${ }^{(15)}$, se não existirem de valores de referência definidos, deverão ser adotadas as referências europeias.

Ora, as European Guidelines ${ }^{(8)}$, já anteriormente referidas, datam de 1996 e não consideram, ainda, o novo paradigma da digitalização de imagem.

Posteriormente, o projeto Dimond $I I I^{(10)}$, também da responsabilidade da Comissão Europeia, tentou adaptar estas normas à nova realidade, não se tendo verificado, no entanto, grandes alterações relativamente ao exame em questão.

Também as normas $A C R^{(11)}$, mais recentes mostram-se muito idênticas, considerando, no entanto, a possibilidade de utilização de diferenças de potencial mais elevadas, aceitando a utilização de valores dentro do intervalo $[120 ; 150] \mathrm{kV}$, sendo possível admitir, para o efeito deste estudo, que a sua utilização conjunta poderá transmitir uma melhor percepção daquilo que se pretende como normas de boas práticas.

No entanto, os diferentes valores de DEP encontrados deixam no ar a questão: Será apenas devido aos diferentes métodos de aquisição de imagem?; Ou as diferentes práticas poderão estar na origem, ou contribuir também, para estas diferenças?

$\mathrm{O}$ valor da diferença encontrado entre a $D E P$ nos dois hospitais, $41 \%$, está de acordo com as referências disponíveis, que apontam para reduções de dose na ordem $\operatorname{dos} 50 \%$, entre a aquisição direta e indireta ${ }^{(13,14)}$.

Desta forma, seria possível aceitar que não seriam as diferenças de procedimentos técnicos, as responsáveis pelas diferenças de DEP observadas nesta avaliação. 
we can try to understand if, in fact, they also contribute to the differences found.

The values of voltages used in Hospital A (125) are programmed by the manufacturer and have not undergone any rectification by the technical team, being suitable for the study in question.

In Hospital $\mathrm{B}$, the use of $137 \mathrm{kV}$ already follows a process of local optimization, considering that, for a normal patient, results in a radiation dose reduction should be taken into account. Given the negative correlation with $E S D$ expected for this variable, it would be permissible to observe an average ESD lower in Hospital B, which did not happen.

For variable mAs, with a strong relationship to the ESD, very pronounced mean differences were observed between Hospitals A and B (1.25 vs 2.74). Considering that in all the exams the $A E C$ and same settings were used, the acquisition of direct digital detectors is clearly more efficient when compared with IPs of indirect digitization.

However, according to information obtained in Hospital $\mathrm{B}$, preventive maintenance had not been undertaken for almost two years and there were no assurances of equipment calibration, which could have influenced the observed $E S D$ values.

The greater mean weight of the Hospital A sample should have resulted in a higher average ESD, which also did not happen.

Moreover, the filtering used in Hospital A was without any additional filtering, implying that a less energetic beam was needed and consequently lower values of ESD. However, the configuration found in Hospital B, with an additional filtering of $1 \mathrm{~mm} \mathrm{Cu}$, is closest to the best practices for all references in relation to chest radiography in PA.

In this analysis, we have identified both variables that are potentially responsible for lower values of ESD observed in Hospital A: filtering, and especially the effectiveness of detectors, with the use of smaller amounts of radiation.

Although it is not possible to establish true comparisons between the values of $D R L s$ available in the literature given the different equipment and methods of calculation involved, the values of $D R L$ determined for both hospitals are lower than most references and are similar to those shown for example by the United Kingdom and South Africa (Fig 2) ${ }^{(16,17)}$.
Considerando as variáveis que mais influenciam a $D E P$ é possível tentar perceber se, de facto, elas também contribuem para as diferenças encontradas.

Os valores de diferenças de potencial utilizados no Hospital A (125), são programados de fábrica e não sofreram qualquer retificação pela equipa técnica, admitindo a sua adequação ao estudo em causa.

Já no hospital B, a utilização de $137 \mathrm{kV}$, decorre dum processo de otimização local, considerando que, para um doente normal, se traduz numa redução de dose de radiação que deveria ser considerada.

Dada a correlação negativa com a $D E P$, esperada nesta variável, seria admissível observar um valor médio de DEP mais baixo no Hospital B, o que não aconteceu. Para a variável mAs, com uma forte relação com a $D E P$, foram observadas diferenças médias muito acentuadas entre os hospitais A e B (1.25 vs 2.74), considerando que em todos os exames foi utilizado CAE e as mesmas configurações de câmaras, fica clara uma maior eficiências dos detetores da aquisição digital direta, quando comparados com os IP's da digitalização indireta.

No entanto e de acordo com informações recolhidas no local, no hospital B, não eram realizadas manutenções preventivas há quase dois anos e não existiam garantias de calibração do equipamento, facto que poderia ter influenciado os valores de $D E P$ observados.

O maior peso médio da amostra do hospital A deveria ter implicado uma maior $D E P$ média, o que também não se verificou.

Também a filtragem utilizada no hospital A, sem qualquer filtragem adicional, deixa implícita a necessidade de um feixe menos energético e consequentemente, com menores valores de $D E P$, no entanto, a configuração encontrada no hospital $\mathrm{B}$, com uma filtragem adicional de $1 \mathrm{~mm}$ de $\mathrm{Cu}$, é a mais próxima das boas práticas indicadas por todas as referências, no que respeita à radiografia de tórax em PA.

Identificam-se, nesta análise, as duas variáveis potencialmente responsáveis pelos menores valores de $D E P$, observados no hospital A, a filtragem e, sobretudo, a eficiência dos detetores, com a utilização de menores quantidades de radiação.

Apesar de não ser possível estabelecer verdadeiras comparações entre os valores de NRD's disponíveis na literatura, dado os diferentes equipamentos envolvidos e métodos de cálculo utilizados, os valores de $N R D$ determinados para ambos os hospitais são inferiores à maioria das referências e semelhantes aos apresentados pelo Reino Unido e África do Sul, por exemplo (Fig. 2) ${ }^{(16,17)}$.

As referências disponíveis sobre NRD's que utilizaram o mesmo método de determinação, calculando os 


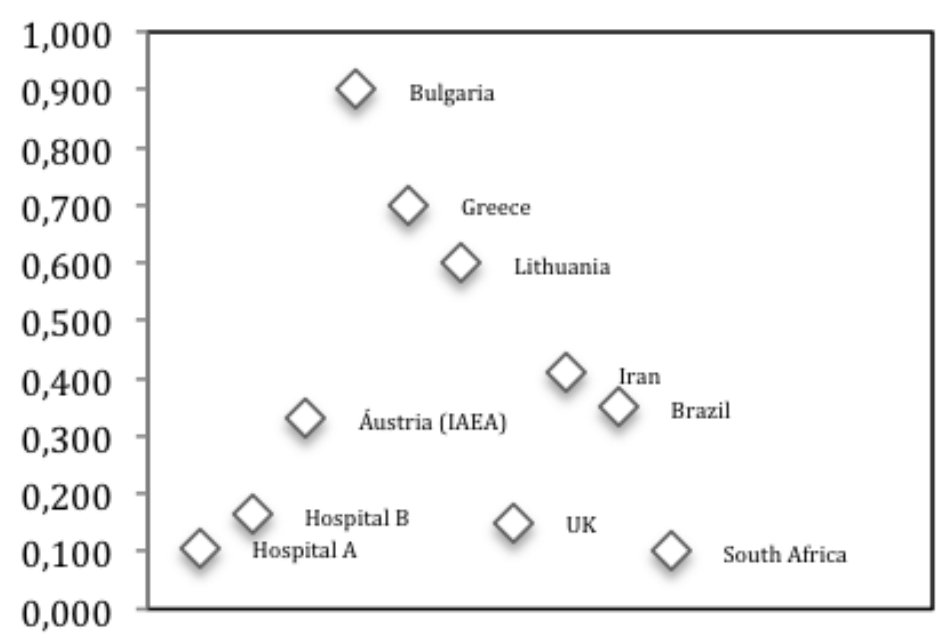

Figure 2 - Distribution of $D R L$ described in literature and the local $D R L$ for both Hospitals.

Figura 2 - Distribuição dos $N R D$ descritos na literatura e dos $N R D$ locais para ambos os Hospitais.

The references available regarding $D R L s$ which use the same method of determining by calculating the values of ESD through the use of technical parameters, such as Austria, Iran and Brazil, showed values significantly higher than those determined by this study, even overtaking reference values indicated by the European Guidelines $^{(8)}\left(0,3\right.$ mGy) (Table 5) ${ }^{(15,16)}$. valores de DEP através da utilização dos parâmetros técnicos, como a Áustria, Irão ou Brasil, mostram valores substancialmente mais elevados que os determinados por este estudo, ultrapassando mesmo os valores de referência indicados pelas European Guidelines $^{(8)}(0,3 \mathrm{mGy})(\text { Tabela } 5)^{(15,16)}$.

Table 5 - Determination method of the $D R L$ as described in the References.

Tabela 5 - Métodos de determinação dos $N R D$ descritos nas Referências.

\begin{tabular}{|l|c|c|}
\hline & DRL's / NRD's $(\boldsymbol{m} \boldsymbol{G y})$ & $\begin{array}{c}\text { Determination Method } \\
\text { Método de Determinação }\end{array}$ \\
\hline Hospital A (Portugal) & 0,107 & $\begin{array}{l}\text { Technical Parameters } \\
\text { Parâmetros Técnicos }\end{array}$ \\
\hline Hospital B (Portugal) & 0,164 & $\begin{array}{l}\text { Technical Parameters } \\
\text { Parâmetros Técnicos }\end{array}$ \\
\hline Austria (IAEA) & 0,33 & $\begin{array}{l}\text { Technical Parameters } \\
\text { Parâmetros Técnicos }\end{array}$ \\
\hline Bulgaria & 0,9 & $\begin{array}{c}\text { Dosimeter } \\
\text { Dosimetro }\end{array}$ \\
\hline Greece / Grécia & 0,7 & $\begin{array}{c}\text { Dosimeter } \\
\text { Dosímetro }\end{array}$ \\
\hline Lithuania & 0,6 & $\begin{array}{l}\text { Dosimeter } \\
\text { Dosimetro }\end{array}$ \\
\hline UK & 0,15 & $\begin{array}{l}\text { Dosimeter } \\
\text { Dosímetro }\end{array}$ \\
\hline Iran / Irão & 0,41 & $\begin{array}{l}\text { Technical Parameters } \\
\text { Parâmetros Técnicos }\end{array}$ \\
\hline Brazil & 0,35 & $\begin{array}{l}\text { Technical Parameters } \\
\text { Parâmetros Técnicos }\end{array}$ \\
\hline South Africa / Africa do Sul & 0,1 & $\begin{array}{l}\text { Technical Parameters } \\
\text { Parâmetros Técnicos }\end{array}$ \\
\hline
\end{tabular}




\section{Conclusion}

The diagnostic reference levels $(D R L s)$ are similar or lower than the international references available both for direct and for indirect digital acquisition.

There was a clear advantage in the use of direct digital system, reducing the radiation dose to the patient for the examination under consideration.

The differences in ESD values found between the two acquisitions systems are consistent with the references found.

Even considering this, in this study, some technical variables may have partially influenced the $E S D$, dose reduction is within the $50 \%$ reduction expected and accepted in the literature.

The variable $\mathrm{mAs}$, as expected, is essential for reduction of radiation dose, and is a primary factor in the attempt to minimize radiation dose.

The study confirmed that, except for filtering at Hospital A, both hospitals apply the best practices and principles of optimization.

\section{Conflict of Interest}

The authors declare that there is no financial or personal relationship that can be understood as representing a potential conflict of interest.

\section{Conclusão}

Os valores de dose de referência $(N R D)$ encontrados são semelhantes ou inferiores às referências internacionais disponíveis, quer para a aquisição digital direta, quer para a indireta.

Verificou-se uma clara vantagem na utilização do sistema digital direto, na redução da dose de radiação para o paciente, para o exame em estudo.

As diferenças de $D E P$ encontradas, entre os dois sistemas de aquisição, são coerentes com as referências encontradas.

Mesmo considerando que, neste estudo, algumas variáveis técnicas podem ter influenciado parcialmente a $D E P$, a redução de dose, situa-se ainda dentro dos $50 \%$ esperados e admitidos na literatura.

A variável mAs, como seria de esperar, é fundamental para a redução das doses de radiação, sendo um fator primordial na tentativa de minimização de doses de radiação.

Verificou-se que, com exceção da filtragem no Hospital A, são aplicadas as boas práticas e os princípios de otimização em ambos os Hospitais.

\section{Conflito de Interesses}

Os autores declaram que não existem quaisquer relações pessoais ou financeiras que possam ser consideradas como um potencial conflito de interesses. 


\section{References / Referências}

(1) Radiation Safety Guidelines (2009). Rev IDEXX LABORATORIES, Vol. 2, 2;

(2) Sandstrom S. The WHO manual of diagnostic imaging: radiographic techniques and projections. World Health Organization; 2003; 1.

(3) Lima J. Técnicas de Diagnóstico com Raios-X: Aspectos Físicos e Biofísicos. $2^{a}$ Ed, Imprensa da Universidade de Coimbra; 2009.p.691-694

(4) PCXMC in: URL: http://www.stuk.fi sateilyn_kaytto/ohjelmat/PCXMC/en_GB/ pcxmc. Acedido a 16/Março/2012.

(5) Mettler F. Medical Radiation Exposure in the U.S. in 2006: Perliminary results. Rev. Health Physics Society; 2008; $502-7$;

(6) Teles P et al. Avaliação da Exposição da População Portuguesa a Radiações Ionizantes devido a Exames Médicos de Radiodiagnóstico e Medicina Nuclear. Dose Datamed 2 Portugal; 2012, 26-35.
(7) Bly R et al (2012) - European Population Dose from Radiodiagnostic Procedures - Results of Dose Datamed 2. Dose Datamed 2, 2012.

(8) European Guidelines on Quality Criteria for Diagnostic Radiographic Images. In: URL: ftp://ftp.cordis.lu/pub/fp5-euratom/docs/ eur16260.pdf. Acedido a 7/Março/ 2012

(9) Comissão Europeia (1999). Orientações relativas aos níveis de referência dignóstico (NRD) para exposições médicas.

(10)Bush H, et al. DIMOND III: Image Quality and Dose Management for Digital Radiography. Trier; 2004; p.5 - 21 .

(11)ACR Practice Guideline for the Performance of Pediatric and Adult Chest Radiography. In: URL: http://www.acr.org/ / media/B40302EE286D4120AAEDE44B409DD45E.pdf. Acedido a 16/Março/ 2012.
(12) Gray J et al. Reference Values for Diagnostic Radiology: Applications and Impact. Rev. RSNA; 2005; 235, 2, p.354-7;

(13) Gruber M et al. Direct Detector Radiography versus Dual Reading Computed Radiography: feasibility of dose reduction in chest radiography. Eur Radiol, 2006; 1544-1550.

(14) Compagnone G et al. Patient Dose in Digital Projection Radiography. Radiation Protection Dosimetry, 2008; 129, p.135-137.

(15)Portugal (2002). Diário da Republica ( 8 de Agosto de 2002) - I Série A, $n^{\circ} 180$.

(16) Nyathi T et al. Patient dose audit for patients undergoing six common radiography examinations: Potential dose reference levels. 2009; 47, 2,p.9- 12.

(17) Matthews K et al. The Applications of Diagnostic Reference Levels: General Principles and an Irish Perspective. Radiography, 2009; 15, p.171-178. 